\title{
Entrepreneurial Orientation, Network Competence and Human Capital: The Internationalization of SMEs in Oman
}

\author{
Shouvik SANYAL ${ }^{1}$, Mohammed Wamique HISAM ${ }^{2}$, Ali Mohsin Salim BAAWAIN ${ }^{3}$ \\ Received: May 25, 2020 Revised: June 07, 2020 Accepted: July 07, 2020
}

\begin{abstract}
Internationalization of SMEs has gathered pace in recent times with falling trade barriers and rising world trade encouraging small firms to seek profits and growth in foreign markets. This has attracted the attention of researchers, and several studies have been conducted in Western nations on the factors influencing the process of SME internationalization. However, hardly any study has been done on SME internationalization in the Gulf Cooperative Council (GCC) region, thus leaving a gap in the literature. This study investigates the influence of four factors, namely, human capital, network competency, entrepreneurial orientation, and market volatility on the degree of internationalization of SMEs in Oman. The study employs survey data collected from 150 SME owners and managers using a structured questionnaire having 27 items, and has been analyzed using correlation and logistic regression, as the dependent variable is binary in nature. The results reveal the impact of the chosen variables on the degree of internationalization of SMEs. The findings of the study suggest that network competency has the highest impact on degree of internationalization of Omani SMEs, followed by human capital and entrepreneurial orientation, while market volatility, though insignificant, moderated the relationship between entrepreneurial orientation and degree of internationalization of Omani SMEs.
\end{abstract}

Keywords: Internationalization, Human Capital, Network Competency, Entrepreneurial Orientation, Market Volatility, Oman

JEL Classification Code: F60, O14, O19, M13, N65

\section{Introduction}

The role of small- and medium-sized enterprises (SMEs) in developing and emerging economies assumes special importance as they are a major source of employment generation and also contribute in boosting export earnings and GDP growth. With access to new and agile technologies

${ }^{1}$ First Author and Corresponding Author. Assistant Professor, Department of Marketing and Entrepreneurship, Dhofar University, Sultanate of Oman [Postal Address: Salalah, 211, Sultanate of Oman] Email: shouviksanyal2000@gmail.com

${ }^{2}$ Assistant Professor, Department of Management Dhofar University, Sultanate of Oman

${ }^{3}$ Lecturer, Department of Marketing and Entrepreneurship Dhofar University, Sultanate of Oman

(C) Copyright: The Author(s)

This is an Open Access article distributed under the terms of the Creative Commons Attribution Non-Commercial License (http://Creativecommons.org/licenses/by-nc/4.0/) which permits unrestricted noncommercial use, distribution, and reproduction in any medium, provided the original work is properly cited. and an appetite and ability to accept risk and uncertainty, emerging market SMEs significantly improved their ability to cross national boundaries and enter challenging new business environments in the quest for growth and profitability. Although several studies have been conducted, which focus on the practice of internationalization of SMEs in advanced economies (Luo et al., 2005; McDougall \& Oviatt, 2003), there is scant research focus on factors influencing the internationalization process of SMEs in emerging market economies (Bruton et al., 2008; Javalgi \& Todd, 2011).

Research on the internationalization of SMEs in the Gulf Cooperation Council (GCC) region is even more scarce, despite this region being home to half a dozen rich and fast growing economies. This is despite the fact that governments in the GCC, including Oman where this study has been done, have realized the strategic importance of SMEs in boosting employment and growth post the global slump in oil prices, which is the main export of this region. This study attempts to fill this gap in the literature in response to the recommendations made by Zahra and George (2002), 
Javalgi and Todd (2011) and Orengo (2012), who proposed that the impact of human capital, entrepreneurial orientation and network relationships on the international expansion of SMEs should be extended to emerging markets.

Oman has been the focus of only a couple of studies when it comes to the entrepreneurship literature dealing with the factors impacting the process and degree of internationalization of SMEs. This is despite the fact that Oman is the fastest-growing economy in the Persian Gulf region and SMEs contribute around 18 percent of the country's GDP. Oman also has the second largest population and land area in the region. The purpose of this research is to expand the literature addressing the relationships between several factors that impact the internationalization process of SMEs in emerging economies such as Oman. The primary research queries addressed in this research are as follows: How is the extent of internationalization of Omani SMEs impacted by entrepreneurial orientation and human capital of the firm? Do network relationships and network competencies play a role in the process of internationalization? What is the impact of market volatility, age and size of the firm on international activities?

As small- and medium-sized firms in emerging economies like Oman develop strategies for entering and operating in a challenging global environment, addressing these issues have become increasingly important. This article focuses on these factors that influence the success of Omani SMEs as they expand globally. Oman is the focal country chosen for this study for the following reasons: the Omani economy has witnessed rapid growth in the last two decades fuelled by petroleum exports. The number of SMEs across industries has grown concurrently, and SMEs contribute nearly 18 percent to Oman's GDP of USD79 billion, make up 15 percent of national export and contribute 30 percent to the manufacturing sector "(NSCI, 2018)". The recent slump in oil prices has led the government to focus on the SME sector to generate employment and boost exports and economic growth. In this context, this study attempts to analyze the critical factors that will aid in the internationalization process of Omani SMEs.

\section{Literature Review}

The international operations of corporates have been growing at a fast pace in the last few decades due to several factors, including globalization, and this phenomenon has attracted the attention of researchers, policymakers and entrepreneurs (Amal \& Filho, 2010). Korsakienè and Tvaronavičien (2012) contend that the phenomenon of internationalization has now become the focal point of research in international entrepreneurship. In the past few years, the spotlight has been on internationalization strategies, and the process of internationalization including modes of entry and speed of internationalization (Solberg \& Durrieu, 2006; Tuppura, Saarenketo, Puumalainen, Jantunen, \& Kyläheiko, 2008). Accordingly, internationalization has been defined in different ways by several authors. Welch and Luostarinen (1988) have described internationalization as 'increasing involvement in international operations'.

According to Javalgi, and White (2003), internationalization is 'a process through which a firm moves from operating in its domestic marketplace to international markets'. Calof and Beamish (1995) are of the opinion that internationalization is 'the process of adopting a firm's operations (strategy, structure and resource, etc.) to environments'. The internationalization of SMEs is a relatively new area of research as most of the previous studies were done on MNEs. Scholars attempted to clearly define the concept of 'SME internationalization'. Ruzzier, Hisrich, and Antoncic (2006) were of the view that internationalization has some distinctive features, and there are significant differences between firm's growth in domestic and international, as opposed to Ghauri and Buckley (1993), who concluded that local growth and internationalization are interrelated.

According to Ruzzier, Antoncic, Hisrich, and Konecnik (2007), each SME has its own unique approach to internationalization and there is no model that fits all. Knight (2001) and $\mathrm{Lu}$ and Beamish (2001) argued that internationalization is an entrepreneurial activity and depends on the orientation of the owners. Daszkiewicz (2004) underlined that the internationalization is composed of a variety of processes including internationalization of markets, production, labor and capital. Buckley and Casson (1976) contend that there are asymmetries in knowledge, technology and capabilities across national boundaries and firms seek to take advantage of these by going international. Dahliah, Kurniawan and Putra (2020) have argued that SMEs contribute to regional development and removes gaps between regions by better utilization of resources. The most commonly and widely accepted models that represent internationalization of firms, albeit with differing assumptions and structures, can be categorized as follows: The Uppsala/stage Model; the Network Model and the Resource-Based View. In addition to these, there are several other proposed models such as the OLI framework.

According to the stage models, in the first phase of going global, companies function only in domestic markets and do not undertake any export activity. Further, firms start exports activity in small quantities, acquiring the needed technology, experience and knowledge that allow them to proceed to the next stage. From this perspective, the process of internationalization is achieved in a sequence of steps that leads to establishing export capability (Daszkiewicz, 2004). The Uppsala model, which is the most well-known 
stage model proposed by Johanson and Vahlne (1990), focuses on how firms gradually acquire the knowledge about foreign markets and then use and integrate this knowledge in their strategies. In particular, attention was focused on the increasing involvement in the individual foreign country. In this model, the result of one stage determines the next step to be taken by the firm. The experiential knowledge in the foreign markets lead to increased confidence, which in turn lead to increased commitments. Thus, cumulative market knowledge leads to incremental steps in internationalization.

The Network Model proposed by Johanson and Mattsson (1988) suggests that firms can overcome their limitations in foreign markets by acquiring resources, technology and knowledge owing to their position in business networks. Hence, this approach believes that firms can successfully internationalize by building and developing significant positions in those foreign networks. Thus, building network relationships is key to successful internationalization. Firms can use those resources under their control within the network to further their relations with other firms that are a part of the network. This in turn means that entrepreneurs need to develop network competencies in order to build network relationships in foreign markets. According to Ivanova and Torkkeli (2013), network competence is defined as the ability of entrepreneurs and managers to develop, manage and maintain relations with key partners, such as suppliers, customers and competitors, and to manage the interactions with them in an effective manner.

The Resource-Based View (RBV) is a model that sees resources as a critical aspect of better performance of the firm. Firms pursue internationalization to exploit the various resources in their possession that can be utilized to create competitive advantage. According to Prahlad and Hamel (1990), resources that are unique, hard to copy and are non-substitutable all help in building the firm's core competencies and result in a durable competitive advantage. These resources may be tangible in the form of physical assets or intangible as in unique technologies and human resources. These resources can be leveraged to access and succeed in foreign markets. In particular, intangible resources such as human capital and international experience of managers can be leveraged successfully to create unique competitive advantages (Barney, Wright, \& Ketchen, 2001).

Several authors have adopted a combination of theories to explain the phenomenon of SME internationalization since each theory cannot explain the process of SME internationalization by itself alone. For example, Cavusgil (2007) states that the internationalization of born global SMEs can be explained by integrating of stage models, network theory, international entrepreneurship (IE) and resource-based view (RBV). Very few researchers who have used the Resource-Based View have focused on the factors such as network competence and relationships, human capital components and its combination with other resources like the entrepreneurial orientation (EO) to explain the internationalization process of SMEs. This is what this research proposes to do, in the context of Omani SMEs.

\section{Hypothesis Development}

\subsection{Human Capital and Internationalization}

Human capital is one of the most important factors that support entrepreneurial growth and expansion as well as economic opportunities. Several scholars have studied the impact of human capital on internationalization and have identified several factors that constitute the human capital. However, there is very little evidence to establish a cause and effect relationship between a firm's human capital and its global expansion, especially in the Arab gulf region. According to Dar and Mishra (2019), human capital consists of experience, talent and skills. Barney (1991) stated that human capital is an intangible resource that creates a sustainable competitive advantage, one that is inimitable and non - substitutable. These include judgment, experience, training, relationships and insights of the people working in a firm.

According to Durrani and Forbes (2003), an organization that invests in human capital is more likely to be successful than one that does not. Access to educated people who are dominant forces of knowledge and have vast experience is a principal factor in achieving higher performance (Vidotto et al., 2017). The employees' skills, education and knowledge are valuable resources of a firm and a lack of adequately qualified staff is an internal barrier that prevents firms from crossing national boundaries (Pinho \& Martins, 2010; Tseng \& Yu, 1991).

Firms can get a competitive advantage from superior human capital (Coleman, 1998) and is accepted as a key factor in firm's performance (Pfeffer, 1994). Human capital plays a critical role in obtaining specific resources for the firm (Brush, Greene, \& Hart, 2001), and it also helps to gain entry to informal networks through personal relationships (Brinlee, Franklin, Bell, \& Bullock, 2004; Glaeser, Laibson, $\&$ Sacerdote, 2002). According to Brush and Chaganti (1998), the education and experience level of managers have a positive correlation with the performance of firms. According to Roos (1998), human capital mainly consists of experience of employees, education, knowledge and this was corroborated by the findings of Coleman (1988) and Becker (1993). Nguyen and Nguyen (2020) have underlined the importance of leadership, organizational culture and working environment in their study on Vietnamese SMEs.

In the contest of firm internationalization, several researchers confirm the positive role played by human 
capital. The degree of internationalization of an SME can be predicted significantly by its human capital (Cerrato \& Piva, 2010; Goxe, 2010; Ruzzier et al., 2007). In the context of Indian SMEs, Javalgi and Todd (2011) found that there human capital positively impacts the degree of internationalization. They further pointed out that education level and international experience of managers are significant elements in predicting the degree of internationalization of firms. Thus, there is quite enough evidence to support the fact that human capital is a critical component in the process of SME internationalization. Although several studies on this have been done by researchers on developed western economies, there are hardly a couple of studies, which focus on this aspect with respect to emerging economies such as Oman.

H1: Human capital has a positive impact on the degree of internationalization of Omani SMEs.

\subsection{Network Relationships and Competence and Internationalization}

Networks are a critical component affecting the internationalization of firms, especially SMEs. Small firms try to access suppliers, customers, distributors etc. in foreign markets through business networks. A network sets of connected exchange relationships between individuals or organizations that involve resource exchange between the different members. The role of networks in the process of internationalization has been widely researched. Chetty and Campbell-Hunt (2003) argue that network relationships involve associations with foreign intermediaries, suppliers, customers, governments and other organizations. Firms utilize these relationships as gateways to access foreign markets and sharing the risks associated with exploring and operating in new markets (Besser \& Miller, 2005; Coviello $\&$ Munro, 1995; Zain, et al, 2006).

SMEs, which are usually lacking in resources, can leverage these networks successfully to gain knowledge about and access to international markets which otherwise would have been very difficult to do. Perry (2007) has postulated that there are four types of networks, namely, personal and ethnic ties, geographical proximity, organizational integration, and buyer-supplier linkages. Associations formed by acquaintances, family and friends help small firms in building social networks and these are based on individual specific relations and the cultural dimension in which the members operate. Mutual trust and commitment are the basis if these ties and the members of the network or community support each other. Examples of these are the Chinese and Indian business communities, which have expanded internationally in several countries in Asia, Europe, Africa and the US. Geographical networks focus on the location or geographical proximity of the firms and involve shared commitment from common values and goals. Examples are the Silicon Valley and chaebols of South Korea.

The network model of internationalization was developed by Johanson and Mattsson (1988) who stated that internationalization is a process in which relationships are formed, grown and ended according to what the objectives of the firm dictate. Coviello and Munro (1995) found out that network relationships play a decisive role in the selection of target market and entry mode as major partners help them in these tasks, among others. Networks also play a significant role in establishing operations, building distribution networks and supplier relationships. All these are invaluable for success in an internationally competitive environment.

Network competencies play a major role in building relationships in networks and have to be assiduously cultivated by small entrepreneurs aspiring to internationalize. According to Ritter, Wilkinson and Johnston (2002), the ability of an SME to establish and maintain relations with intermediaries, customers and other organizations both at home and abroad and to successfully manage these interactive relationships are a part of the core competence of the firm and this is referred to as the firm's network competence. Without strong competencies in building network relationships, it is very difficult for an SME to leverage the benefits of network relationships. There is very little literature pertaining to the importance and development of network competencies in emerging markets.

H2: Network competency has a positive impact on the degree of internationalization of Omani SMEs.

\subsection{Entrepreneurial Orientation and Internationalization}

Entrepreneurial orientation is a construct that is characterized by managerial philosophies, firm behavior, personal managerial skills and traits that are entrepreneurial in nature. A firm's entrepreneurial orientation allows an SME to seek directions for growth and enables entry into new markets (Covin \& Slevin, 1991). Entrepreneurial orientation is directly linked to and influences the network relationships of the firm. This construct has been used to understand the long-term commitment of executives to business performance of small and- medium sized-firms and how it can be used to create value (Orengo, 2012). Several studies have highlighted the role of entrepreneurial orientation in the internationalization process of SMEs. The dimensions that have been used to describe entrepreneurial orientation include autonomy, innovativeness, proactiveness, risk taking, and competitive aggressiveness (Wiklund \& Shepherd, 2003; Orengo, 2012). 
Autonomy refers to the ability of an individual or team to independently create an idea or vision and carry it to fruition. Any action that is taken independently of organizational constraints is autonomy (Lumpkin \& Dess, 1996). Innovation is the firm's attitude towards new ideas, introducing new products and services and supporting change (Kuratko \& Hodgetts, 2004). Proactiveness refers to recognizing and seizing market opportunities e.g., introducing new products etc., before the competition (Antoncic \& Hisrich, 2003). Risk taking refers to the ability to take bold actions such as entering new markets, while avoiding unnecessary risks (Lumpkin \& Dess, 1996). Autonomy, managerial competence, technical competence and creativity have a direct impact on entrepreneurial creativity (Lee \& Kim, 2019). Competitive aggressiveness can be described as a response to threats or a tendency to take on competitors head-on (Antoncic et al., 2003). All these dimensions have been used by researchers to understand the performance of SMEs in international context (Todd \& Javalgi, 2011, McDougall et al., 2000; Wiklund \& Shepherd, 2003). Since all international activities are entrepreneurial in nature as there is an inherent acceptance of risk and the need to innovate and adapt, positive entrepreneurial orientation is necessary to use these characteristics to create value in an international market (Fletcher, 2004).

H3: Entrepreneurial orientation of Omani SME has a positive impact on the degree of internationalization.

\subsection{The Impact of Market Volatility}

There are several environmental factors that can moderate the relationship between entrepreneurial orientation and export performance of SMEs. Market volatility refers to the amount of change that takes place within the business environment. Due to the multiplicity and variability of the factors, international business environments tend to be more volatile than domestic ones. Oman is located in the Arab gulf region, which has a long history of geopolitical tensions, which make the environment all the more volatile. In the recent past, trade frictions between US and China and the slump in oil prices combined with renewed tensions in the Middle East have all added to the market volatility for SMEs in Oman. The slowing down of economies of India and China, both important trading partners of Oman, have also added to the volatility and uncertainty.

Researchers have found a significant and positive relationship between firm performance and entrepreneurial orientation in times of high market volatility (Kaya \& Seyrek, 2005) and the moderating effect of environmental turbulence has been recognized and acknowledged (Kohli \& Jaworski, 1990). The firm's operating environment is the sum total of all domestic factors affecting the firm's ability to operate as well as the foreign influences that have a positive or negative impact. Managers have to recognize the impact and significance of volatility in the international environments and must be innovative and aggressive enough to take calculated risks that will allow them to operate in the complex environment. This needs a certain type of orientation on the part of the management of SMEs (Zahra \& Nebaum, 2017). The firms' reaction to environmental and market turbulence influences its performance (Heide \& Weiss, 1995).

H4: Market volatility has a moderating effect on the relationship between degree of internationalization and entrepreneurship orientation of Omani SMEs.

\section{Research Methodology}

\subsection{Research Instrument}

In the first step, the literature was used to develop the survey instrument to collect data. The data collection instrument in this study is a structured questionnaire that uses a 5-point Likert scale ranging from 1 to 5, where 1 stands for "strongly disagree" and 5 stands for "strongly agree". The questionnaire consisted of 27 items covering all the variables and questions are in English and Arabic considering the fact that many respondents may not be very conversant with the English language.

\subsection{Sampling}

The sample frame for this study was drawn from the list of SMEs provided by the Oman Chamber of Commerce and Industry (OCCI). This is an exploratory research and the data consisted of SMEs across industries located across Oman, and 150 respondents were randomly selected from this list representing a cross-section of industries, most of them being in the manufacturing sector. The respondents are located across all governorates in Oman.

\subsection{Data Collection}

The questionnaire was sent electronically by email to the owner/person in charge of international operations. Prior to this, the respondents were checked to ensure that their employee size is less than 500 (as per definition of SMEs in Oman) and that they were involved in business operations. The data consisted of 150 random responses, representing one response per firm. Nearly 40 percent of sampled SMEs had less than 50 employees, twenty percent had between 50 and 100 employees and the remaining had between 100 and 500 employees. Out of the questionnaires sent, only 130 were returned and 4 were incomplete thus leaving an effective sample size of 126. 


\section{Development of Scales}

\subsection{Human Capital Scale}

The educational level of managers and their years of international experience have been used in a number of studies to measure human capital (Orengo, 2012; Dimov \& Shepherd, 2005; Dar \& Mishra 2019). The current study has used the scale proposed by Dar and Mishra (2019) to measure the human capital of the firm. This scale has used two dimensions of education level and experience of employees to explain the human capital of the firm. Each dimension has five items and, thus, there are ten items in all. The dimension reduction process has eliminated three items due to poor factor loadings so there are seven items left, which have then been subjected to Confirmatory Factor Analysis to further qualify the results. The scale's fit indices as per CFA were good (chi-square/df $=2.03, \mathrm{CFI}=0.94$, $\mathrm{NFI}=0.92$, RMSEA $=0.07$ ).

\subsection{Network Competency Scale}

The network competency scale used to measure the efforts to utilize network relationships consisted of three items and was based on the scale developed by "Ritter, Wilkinson and Johnston (2002)". Each item was measured on a 5-point Likert scale and the items focus on the competencies needed to establish successful international business networks. All three items in the scale loaded well on a single factor, which accounted for $80 \%$ of variance in the factor. The fit indices of the scale were confirmed by CFA.

\subsection{Entrepreneurial Orientation Scale}

The construct of entrepreneurial orientation used in this study is based on the scale developed by Covin and Slevin (1989) and further validated by Orengo (2012). This EO construct has three dimensions, namely, innovativeness, risk taking, and proactiveness to measure the degree of firm's internationalization. Each dimension has three items, so there are nine items in total. Each item is measured on a 5-point Likert scale. This scale has been used several times and thus possesses high levels of reliability and validity measures (Orengo, 2012; Ripolles-Melia et al., 2007; Zahra et al., 2005). The principal component analysis has eliminated two items from the scale and the remaining seven items have been subjected to Confirmatory Factor Analysis to confirm the results further. The scale's fit indices as per CFA were good (chi-square/df $=1.84$ (Hair, et al, 2010), CFI $=0.95$, $\mathrm{NFI}=0.94, \mathrm{RMSEA}=0.05)$. All items loaded well on the first and second factors.

\subsection{Market Volatility Scale}

Market volatility in this study is based on the scale developed by Jaworski and Kohli (1993), which was composed of four items, each item being measured on a 5-point Likert scale where 1 indicates that the respondent strongly disagrees with the statement and 5 indicates strong agreement. One item with low loading was removed during CFA analysis and so three items are left. The scale's validity and reliability has been confirmed in several studies.

\subsection{Measure of Degree of Internationalization}

The most commonly-used measure to understand the degree of a firm's international performance is International Sales as a percentage of Total Sales (ISTS), which has been used in several research studies such as Sullivan (1994). In this study, an SME is considered to be international if the foreign sales in a particular year constitute more than $25 \%$ of total sales, in which case the variable takes a value of one; otherwise it is zero. Thus, the dependent variable is binary in nature, i.e., it takes a value of either zero or one based on percentage of foreign sales.

\subsection{Control Variables}

The two control variables used in this study are size and age of the firm. The size of the firm was defined by the number of employees, and the age was the number of years that the firm has been in operation.

\section{Results}

The Likert-type scales used to develop the constructs were checked for reliability and validity. The psychometric properties of the measurement scales have already been validated by previous studies. The reliability of each item was checked using Cronbach's Alpha, which is a measure of internal consistency of a scale. It is a widely-used measure of scale reliability and alpha values of over 0.70 indicate that the measures are reliable. The alpha values of all the items were found to be higher than 0.70 , thus showing that the items are reliable.

The construct validity of an operationalization or measurement is the extent to which it really measures what it claims to measure. Principal Component Analysis was conducted to assess the construct validity of the constructs. PCA is a dimension reduction technique, which is used when the variables are strongly correlated, as is the case in this study. The principal component analysis method has been applied for extraction and method of varimax for rotation. The results of the PCA in the form of factor loadings indicated that the measurement scales showed both convergent and 
discriminant validity of the constructs. Most researchers agree that convergent validity is achieved when the factor loadings are more than 0.70 (Bagozzi, 1981; Nunally, 1978) all CR values are more than 0.76 and the AVE of each factor component is greater than 0.50 (Anderson \& Gerbing, 1988). Discriminant validity refers to the extent to which factors are distinct and uncorrelated. The factor analysis excluded the items with poor factor loadings, and two items in the entrepreneurial orientation scale, three items in the human capital scale and one item in the market volatility scale were excluded as the factor loadings were less than 0.50 , which is the minimum value for this sample size "(Hair,2010)". Thus, all items are reliable and valid for further analysis. The values of the reliability and validity measures can be seen in Table 1.

Results of the correlation analysis are shown in Table 2. The correlations are not high enough to cause problems of multicollinearity. International experience of employees and their educational level have the highest correlations with the degree of internationalization of firm, followed by network competency and entrepreneurial orientation.

The data was analyzed using logistic regression. Logistic regression is used when the dependent variable is binary rather than continuous. In this study, the dependent variable i.e., Degree of Internationalization is binary having value of one or zero. Logistic regression has been extensively used by researchers to study the method of market entry in order to predict the occurrence of internationalization of firms (Javalgi \& Todd, 2011). The function of the logistic regression can be expressed as follows:

$\mathrm{P}(\operatorname{mode}$ choice $=1)=\left[1 /\left(1+\mathrm{e}^{-\mathrm{Y}}\right)\right]$

Where, $Y=\beta+\beta X_{1}+\beta X_{2}+\beta X_{3}+\ldots \ldots \ldots+\beta X_{k}$ and $X_{1}$, $\mathrm{X}_{2}, \mathrm{X} 3 \ldots . . \mathrm{X}_{\mathrm{k}}$ are the covariates.

Table 3 shows the results of the logistic regression. As can be seen from Table 3, the percent of cases classified is $72 \%$, which indicates that the independent variables (human capital, network competency and entrepreneurial intention) are good predictors of the dependent variable i.e., degree of internationalization. As evident in Table 3 , both dimensions of human capital that is, educational level of employees (beta $=$ $0.48, p<0.01$ ) and international experience (beta $=0.62, p<$ 0.05 ) were significant; thus showing that human capital has a positive impact on the degree of internationalization of Omani SMEs, confirming hypothesis H1. In addition, the impact of network competency on internationalization was also significant (beta $=0.78, p<0.05$ ), thus confirming hypothesis $\mathrm{H} 2$. The results also show that entrepreneurial orientation is positively related to the degree of internationalization of Omani SMEs (beta $=0.42 ; p<0.01$ ), thereby confirming H3.

However, the coefficient of the moderator variable (Market Volatility) was not significant (beta $=0.04, p=0.30$ ).

Table 1: Validity and Reliability Results

\begin{tabular}{|l|c|c|c|}
\hline \multicolumn{1}{|c|}{ Variable } & Cronbach Alpha( $\boldsymbol{\alpha})$ & CR & AVE \\
\hline Human Capital & 0.860 & 0.789 & 0.606 \\
\hline Network Competency & 0.819 & 0.942 & 0.636 \\
\hline Entrepreneurial Orientation & 0.780 & 0.845 & 0.681 \\
\hline Market Volatility & 0.875 & 0.837 & 0.738 \\
\hline
\end{tabular}

Table 2: Correlation Matrix

\begin{tabular}{|c|l|c|c|c|c|c|c|c|}
\hline \multicolumn{2}{|l|}{ Variables } & $\mathbf{1}$ & $\mathbf{2}$ & $\mathbf{3}$ & $\mathbf{4}$ & $\mathbf{5}$ & $\mathbf{6}$ & $\mathbf{7}$ \\
\hline 1. & DOI & 1 & & & & & & \\
\hline 2. & Net.Comp & $0.46^{\mathrm{a}}$ & 1 & & & & & \\
\hline 3. & EO & $0.36^{\mathrm{a}}$ & 0.12 & 1 & & & & \\
\hline 4. & Mkt.Vol. & 0.20 & 0.06 & 0.08 & 1 & & & \\
\hline 5. & Edu. & $0.53^{\mathrm{a}}$ & 0.12 & 0.04 & 0.06 & 1 & & \\
\hline 6. & Int'l. Exp. & $0.55^{\mathrm{a}}$ & $0.56^{\mathrm{b}}$ & 0.14 & $0.13^{\mathrm{a}}$ & 0.11 & 1 & \\
\hline 7. & Age & 0.23 & $0.42^{\mathrm{a}}$ & 0.02 & $0.15^{\mathrm{a}}$ & 0.10 & $0.35^{\mathrm{a}}$ & 1 \\
\hline 8. & \# of Emp. & 0.13 & 0.08 & $-0.18^{\mathrm{a}}$ & $-0.24^{\mathrm{a}}$ & $0.22^{\mathrm{a}}$ & 0.02 & 0.04 \\
\hline
\end{tabular}

$\mathrm{DOI}=$ degree of internationalization; Net.Comp, = network competency; EO = entrepreneurial orientation; Mkt. Vol. = market volatility; Edu = level of education $=$ Int'l. Exp. $=$ international experience; Age $=$ age of the firm; $\#$ of Emp. = number of employees; $p<0.05 . p<0.01$. 
Table 3: Logistic Regression Results

\begin{tabular}{|l|c|}
\hline \multicolumn{1}{|c|}{ Variables } & \multicolumn{1}{|c|}{$\begin{array}{c}\text { Parameter } \\
\text { Estimates }\end{array}$} \\
\hline Human capital (HC) & \\
\hline Educational level (EDU) & $0.48^{\mathrm{b}}$ \\
\hline International experience (INTEXP) & $0.62^{\mathrm{a}}$ \\
\hline Network Competency (NC) & $0.78^{\mathrm{a}}$ \\
\hline Entrepreneurial orientation (EO) & $0.42^{\mathrm{b}}$ \\
\hline Market Volatility(MV) & 0.04 \\
\hline Moderator & \\
\hline MV x EO & $0.59^{\mathrm{b}}$ \\
\hline Control variables & \\
\hline Age of the firm & $0.52^{\mathrm{a}}$ \\
\hline Size & 0.09 \\
\hline
\end{tabular}

Percent of case: correctly classified $=72 \%$. Chi-Square $=36.55 .-2$ log likelihood $=76.39$.

aP $<0.01 . P<0.05$.

The coefficient of the multiplicative interaction between entrepreneurial orientation and market volatility was significant (beta $=0.59, \mathrm{p}<0.01$ ), thereby confirming $\mathrm{H} 4$. The age of the firm was significant (beta $=0.52, \mathrm{p}<0.05$ ), but the size of the firm was not found to be significant in the degree of internationalization.

\section{Discussion}

Oman, which is considered a fast-growing emerging market and the fastest-growing economy in the GCC region (NSCI, 2018), is playing an increasingly important role in the international markets due to its diversified exports to several Asian, African and European countries. Products made in Oman are now sold in over 100 countries and the government has employed renewed focus on SMEs in the quest to diversify the economy away from petroleum products. This study focuses on the internationalization of Omani SMEs and has several research and managerial implications. From the research point of view, the study adds to the scant existing literature about the role played by human capital, network competencies and entrepreneurial orientation in explaining the process of internationalization of Omani SMEs. The results of the study support the first hypothesis that human capital has a positive impact on the degree of internationalization of Omani SMEs. The international market experience and educational level of SME owners and managers were found to be significant predictors of the degree of internationalization of SMEs in Oman. This supports the findings of several researchers who have opined that as a firm gains international experience and understand the dynamics of foreign markets in a better fashion, they will intensify their internationalization efforts.

Network competency, which is a significant factor in creating network relations (Ivanova \& Torkkeli, 2013), has also been found to positively impact the degree of internationalization of SMEs in Oman. Several studies in western countries have found that network competencies of owners and managers play a significant role in enhancing the international performance of SMEs by helping forge relationships with important suppliers, customers, government agencies and other organizations in foreign markets. This helps the SMEs to leverage the resources of foreign partner in successful market entry, distributions and sales. Thus, owners and managers of MSEs have to orient their employees to develop these competencies, including language and communication skills and ability to contact and establish network relationships with foreign partners. It has been conclusively proved that SMEs with network relationships are able to utilize their positions in these networks to become successful in international environments.

This study has also found a strong and positive relationship between entrepreneurial orientation and the degree of internationalization of SMEs in Oman. This also supports the findings of numerous research studies (Autio et al., 2000), which studied the relationships between these two variables. Thus, there is a need for top level managers in small firms to foster an entrepreneurial culture and an eagerness to explore foreign markets throughout the organization. Employees have to be trained to scan for and recognize opportunities in foreign markets and develop products / services according to the needs of these markets. In this way, it is possible to seize the enormous opportunities that exist in global markets.

Zahra and Garvis (2000) and Besser and Miller (2005) have found in their studies on international American firms that market volatility significantly moderates the relationship between international entrepreneurship and company performance. In other words, as market volatility increases, there is a higher chance that firms will seek to expand internationally and the owners and managers can positively affect the firm performance. The results of this study support this viewpoint. The control variables of age and size of the firm also have been found to have a significant impact on the internationalization of Omani SMEs. This shows that firms that are expanding in size are better positioned to leverage the experience, resources, skills and knowledge gathered over time in the quest to internationalize (Zhou, 2007; Chelliah, 2010).

\section{Conclusion and Limitations}

The process of internationalization of firms has attracted the attention of researchers worldwide, but little efforts 
have been devoted to understand the factors affecting the internationalization of MSEs, especially in emerging markets. This study adds to the existing body of knowledge on the process of internationalization by focusing on SMEs in an emerging market like Oman. The study also supports and validates the findings of several studies on internationalization previously conducted in western countries. The research is based on empirical data and also provides a theoretical framework by identifying some key factors and behaviors (e.g., risk taking, networking) that will help SMEs in Oman to build sustainable competitive advantage in highly complex and dynamic business environments. However, in spite of all the positive aspects, the study also has its limitations. The first limitation is that the study is cross-sectional in nature and hence the conclusions are tentative in nature. The relationship between human capital, network competency, entrepreneurial orientation, and degree of internationalization should be measured longitudinally for better results. Also, the constructs used in the study do not capture all the elements, for example network competency does not capture all the inherent elements of network competency as there are several. There is a need to use other constructs having more measurable including external factors like competition, market saturation, attractive policies in certain markets etc., to study the motives for internationalization.

Also, the moderator used in the study (market volatility) is based on the available literature. The impact of other moderators can be considered for further studies. The study will also be strengthened by a multiple country analysis since this one is based only in one country. By replicating this study in other markets, researchers can get a better understanding of the impact of these constructs on internationalization of SMEs in those countries. As SMEs continue to grow and expand internationally, there are ample opportunities to develop a range of models that explain the phenomenon of entrepreneurial internationalization behavior of SMEs in emerging markets.

\section{References}

Amal, M., \& Filho, A. R. F. (2010). Internationalization of smalland medium-sized enterprises: A multi case study. European Business Review, 22(6), 608-623.

Anderson, J. C., \& Gerbing, D. W. (1988). Structural equation modeling in practice: a review and recommended two-step approach. Psychology Bulletin, 103(3), 411-423.

Antoncic, B., \& Hisrich, R. D. (2003). Clarifying the entrepreneurship concept. Journal of Small Business and Enterprise Development, 10(1), 7-24.

Autio, E., Sapienza, H. J., \& Almeida. J. G. (2000). Effects of age at entry, knowledge intensity, and imitability on international growth. Academy of Management Journal, 43(5), 909-924.
Bagozzi, R. P. (1981). Evaluating structural equation models with unobservable variables and measurement error: a comment. Journal of Marketing Research, 18(3), 375-381.

Barney, J. (1991). Firm's resources and sustained competitive advantage. Journal of Management, 1(1), 99-120.

Barney, J., Wright, M., \& Ketchen, D. J. (2001). The Resource Based View of the Firm: Ten Years after 1991. Journal of Management, 6, 625-641.

Becker, G. S. (1993). Human Capital: A theoretical and empirical analysis, with special reference to education. Chicago, IL: The University of Chicago Press.

Besser, T., \& Miller, N. (2005). Exploring Decision Strategies and Evaluations of Performance by Networked US Small Businesses. Journal of Development Entrepreneurship, 10(2), 167-186.

Brinlee, J. B., Franklin, G. M., Bell, J. R., \& Bullock, C. A. (2004). Educating entrepreneurs on angel venture capital financing options. Journal of Business and Entrepreneurship, 16(2), 141.

Brush, C. G., Greene, P. G., \& Hart, M. M. (2001). From initial idea to unique advantage: The entrepreneurial challenge of constructing a resource base. The Academy of Management Executive, 15(1), 64-78.

Brush, C., \& Chagant, R. (1998). Business without glamor? An analysis of resources on performance by size and age in small service retail firms. Journal of Business Venturing, 14, 233-57.

Bruton, G. D., Ahlstrom, D., \& Obloj, K. (2008). Entrepreneurship in emerging economies: where are we today and where should the research go in the future. Entrepreneurship Theory Practice, 32(1), 1-14.

Buckley, P. J., \& Casson, M. C. (1976). The future of the multinational enterprise. ( $\left.1^{\text {st }} \mathrm{ed}\right)$. London, UK: Macmillan Publications.

Calof, J. L., \& Beamish, P. W. (1995). Adapting to foreign markets: Explaining internationalization. International Business Review, 4(2), 115-131.

Cavusgil, S. T. (2007). Toward a Typology of Commitment States among Managers of Born-Global Firms: A Study of Accelerated. Journal of International Marketing, 15(4), 1-40.

Cerrato, D., \& Piva, M. (2012). The internationalization of small and medium-sized enterprises: The effect of family management, human capital and foreign ownership. Journal of Management \& Governance, 16(4), 617-644.

Chelliah. S., Pandian, S., Bin Sulaiman, M., \& Munuswamy,J. (2010). The moderating effect of firm size: Internationalization of small and medium enterprises (SMEs) in the manufacturing sector. African Journal of Business Management, 4(14), 30963109.

Chetty, S., \& Campbell-Hunt, C. (2003). Explosive International Growth and Problems of Success amongst Small and Mediumsized Firms. International Small Business Journal, 27(1), 5-27.

Coleman, J. (1998). Social capital in creation of human capital. American Journal of Sociology, (94), 95-120. 
Coviello, N. E., \& Munro, H. J. (1995). Growing the Entrepreneurial Firm: Networking for International Market Development. European Journal of Marketing, 29, 49-61.

Covin, J, G., \& Slevin, D. P. (1991). A Conceptual Model of Entrepreneurship as Firm Behavior. Entrepreneurship: Theory and Practice, 16(1), 7-24.

Dahliah, D., Kurniawan A., \& Putra, A. H. P. K. (2020). Analysis and Strategy of Economic Development Policy for SMEs in Indonesia. Journal of Asian Finance, Economics and Business, 7(5), 103-110. https://doi.org/10.13106/jafeb.2020.vol7. no5.103

Dar, I. A., \& Mishra, M. (2019). Human Capital and SME's Internationalization: Development and Validation of a Measurement Scale. Global Business Review, 10(2), 1-17.

Daszkiewicz, N., \& Wach, K. (2004). Internationalization of SMEs: Context, Models and Implementation. Gdańsk University of Technology Publishing.

Dimov, D. P., \& Shepherd, D. A. (2005). Human capital theory and venture capital firms: Exploring "home runs" and "strike outs". Journal of Business Venturing, 20(1), 1-21.

Durrani, T. S., \& Forbes, S. M. (2003). Intellectual capital and technology strategy. In: Managing Technologically Driven Organizations: The Human Side of Innovation and Change (pp. 151-155). Engineering Management Conference, IEEE. November 2003, Cambridge, MA.

Ghauri, P. N., \& Buckley, P. J. (1993). The internationalization of the firm: A reader. Waltham, MA: Academic Press.

Glaeser, E. L., Laibson, D., \& Sacerdote, B. (2002). An economic approach to social capital. The Economic Journal, 112(483), 437-458.

Goxe, F. (2010). Human and social capital interplay among internationalizing SMEs. Journal of Knowledge-based Innovation in China, 2(1), 73-88.

Hair, J. F, Black, W. C., Babin, B. J., \& Anderson, R. E. (2010). Multivariate Data Analysis ( $7^{\text {th }}$ ed.). Chicago, IL: Pearson Publications.

Heide, J. B., \& Weiss, A. M. (1995). Vendor consideration and switching behavior for buyers in high- technology markets. Journal of Marketing, 59(3), 30-44.

Ivanova, L., \& Torkkeli, M. (2013). Managerial sensemaking of interaction within business relationships: A cultural perspective. European Management Journal, 31(6), 717-727.

Javalgi, R. R. G., \& Todd, P. R. (2011). Entrepreneurial orientation, management commitment, and human capital: The internationalization of SMEs in India. Journal of Business Research, 64(9), 1004-1010.

Javalgi, R. R. G., Griffith, D. A., \& Steven White, D. (2003). An empirical examination of factors influencing the internationalization of service firms. Journal of Services Marketing, 17(2), 185-201.
Johanson J., \& Mattsson, L.G. (1998). Internationalization in Industrial System - A Network Approach, Journal of Intellectual Capital, 18(2), 316-329.

Johanson, J., \& Vahlne,J.E. (1990). The mechanism of internationalization. International Marketing Review, (40), 1124.

Kaya, N., \& Seyrek, I. H. (2005). Performance impacts of strategic orientation: evidence from Turkish manufacturing firms. Journal of American Academy of Business, 4(3), 68-72.

Knight, G. A. (2001). Entrepreneurship and strategy in the international SME. Journal of International Management, 7(3), 155-171.

Kohli, A., \& Jawroski, B. (1990). Market Orientation: the Construct, Research Propositions and Managerial Implications. Journal of Marketing, 54, 1-18.

Korsakienè, R., \& Tvaronavičienè, M. (2012). The internationalization of SMEs: An integrative approach. Journal of Business Economics and Management, 13(2), 294-307.

Kuratko, D. F., \& Hodgetts, R.M. (2004). Entrepreneurship: Theory, Process and Practice. ( $6^{\text {th }}$ ed). Mason, $\mathrm{OH}$ : Thompson South-Western.

Lee, W. S., \& Kim, B. Y. (2019). The Effects of Career Orientations on Entrepreneurial Satisfaction and Business Sustainability. Journal of Asian Finance, Economics and Business, 6(4), 235248. https://doi.org/10.13106/jafeb.2019.vol6.no4.235

Lu, J. W., \& Beamish, P. W. (2001). The internationalization and performance of SMEs. Strategic Management Journal, 22(67), 565-586.

Lumpkin, G. T., \& Dess, G. (1996). Clarifying the Entrepreneurial Orientation Construct and Linking It to Performance. The Academy of Management Review, 21(1), 135-172.

Luo, X., Zhou, L., \& Liu. S. S. (2005). Entrepreneurial firms in the context of China's transition economy: an integrative framework and empirical examination. Journal of Business Research, 58(3), 277-284.

McDougall, P. P., \& Oviatt, B. M. (2000). International entrepreneurship: the intersection of two research paths. Academy of Management Journal, 43(5), 902- 906.

McDougall, P. P., Oviatt, B. M., \& Schrader, R. C. (2003). A comparison of international and domestic new ventures. Journal of International Entrepreneurship, 1(1), 59-82.

NCSI Knowledge-index. (2018). National Center for Statistics and Information. Oman: NCSI. Available from: https://www. ncsigovom/ pages/ncsiaspx.

Nguyen, H. H., Nguyen T. T., \& Nguyen P. T. (2020). Factors Affecting Employee Loyalty: A Case of Small and Medium Enterprises in Tra Vinh Province, Viet Nam. Journal of Asian Finance, Economics and Business, 7(1), 153-158. https://doi. org/10.13106/jafeb.2020.vol7.no1.153

Nunnally, J. C. (1978). Psychometric theory (2nd ed). New York, NY: McGraw Hill Publications. 
Orengo, K. L. (2012). Internationalization and Entrepreneurial Orientation, a Network perspective: Four cases of Puerto Rican SMEs. AD-minister, 21, 55-69.

Perry, M. (2007). Small Firms and Network Economies. In: Routledge Studies in Small Business. London, UK: Routledge.

Pfeffer, J. (1994). Competitive advantage through people. California Management Review, 36(2), 9-28.

Pinho, J. C., \& Martins, L. (2010). Exporting barriers: Insights from Portuguese small-and medium-sized exporters and nonexporters. Journal of International Entrepreneurship, 8(3), 254-272.

Prahalad, C. K., \& Hamel, G. (1990). The core competence of the corporation. Harvard Business Review, 68(3), 79-91.

Ripolles-Melia, M., Menguzzato-Boulard, M., \& Sanchez-Peinado, L. (2007). Entrepreneurial orientation and international commitment. Journal of International Commitment, 5, 65-83.

Ritter, T., Wilkinson, I. F., \& Johnston, W. J. (2002). Measuring Network Competence: Some International Evidence. Journal of Business \& Industrial Marketing, 17(2), 119-138.

Roos, J. (1998). Exploring the concept of intellectual capital (IC). Long Range Planning, 31(1), 150-153.

Ruzzier, M., Antoncic, B., Hisrich, R. D., \& Konecnik, M. (2007). Human capital and SME internationalization: A structural equation modeling study. Canadian Journal of Administrative Sciences, 24(1), 15-29.

Ruzzier, M., Hisrich, R. D., \& Antoncic, B. (2006). SME internationalization research: Past, present, and future. Journal of Small Business and Enterprise Development, 13(4), 476-497.

Solberg, C. A., \& Durrieu, F. (2006). Access to networks and commitment to Internationalization as precursors to marketing strategies in international markets. Management International Review, 46(1), 57-83.

Tseng, J. Y., \& Yu, C. M. J. (1991). Export of industrial goods to Europe: The case of large Taiwanese firms. European Journal of Marketing, 25(9), 51-63.
Tuppura, A., Saarenketo, S., Puumalainen, K., Jantunen, A., \& Kyläheiko, K. (2008). Linking knowledge, entry timing and internationalization strategy. International Business Review, 17(4), 473-487.

Vidotto, J. D. F., Ferenhof, H. A., Selig, P. M., \& Bastos, R. C. (2017). A human capital measurement scale. Journal of Intellectual Capital, 18(2), 316-329.

Welch, L. S., \& Luostarinen, R. (1988). Internationalization: Evolution of a concept. Journal of General Management, 14(2), 34-55.

Wiklund, J., \& Shepherd, D. (2003). Knowledge-based resources, entrepreneurial orientation, and the performance of small and medium-sized businesses. Strategic Management Journal, 24, 1307-14.

Zahra, S. A., \& Garvis, D. M. (2000). International corporate entrepreneurship and firm performance: the moderating effect of international environmental hostility. Journal of Business Venturing, 15, 469-492.

Zahra, S. A., \& George, G. (2002). International entrepreneurship: the current status of the field and future research agenda. In: Hitt, M. A., Ireland, R. D., Camp, S. M., Sexton, D. L. (eds.), Strategic Entrepreneurship: Creating a New Mindset (pp. 255288). Oxford, UK: Blackwell.

Zahra, S. A., \& Neubaum, D. O. (2017). Environmental adversity and entrepreneurial activities of new ventures. Journal of Developmental Entrepreneurship, 3(2), 123-140.

Zahra, S. A., Korri. J. S., \& Yu, J. F. (2005). Cognition and international entrepreneurship: implications for research on international opportunity recognition and exploitation. International Business Review, 14(2), 129-146. https://doi. org/10.1016/j.ibusrev.2004.04.005

Zain, M., \& Imm Ng, S. (2006). The Impacts of Networks Relationships on SMEs Internationalization Process. Thunderbird International Business Review, 48(2), 183-205.

Zhou, L. (2007). The effects of entrepreneurial proclivity and foreign market knowledge on early internationalization. Journal of World Business, 42(3), 281-293. 